\title{
EFFECT OF HOUSING CONDITIONS ON PERFORMANCE OF JAPANESE QUAIL (Coturnix coturnix japonica) UNDER COLD STRESS IN WINTER
}

\author{
H.A. Khalil ${ }^{1}$, A.M. Hassanein ${ }^{1}$, M.E. Mady $^{1}$ and M. Gerken ${ }^{2}$ \\ 1- Department of Animal Production, Faculty of Agriculture, University of Suez \\ Canal, Ismailia, Egypt, 2- Institute of Animal Breeding and Genetics, University of \\ Goettingen, Albrecht Thaer Weg 3, 37075 Goettingen, Germany
}

\section{SUMMARY}

The effect of different housing conditions on body weight, weight gain, feed intake, water consumption, egg production, rectal temperature, hematocrit value and mortality rate were studied in Japanese quail. Three experimental groups: winter conditions (control), long day-light (lighted) and hot climate (heated) were used. A total of 195 quail chicks (65/group, 40 females and 25 males) were used. Results showed that significant differences in the most studied traits occurred among the treatment groups. Winter conditions had a significantly lighter body weight compared to the other groups between 6 to 14 weeks of age. During this period, rectal temperature was significantly higher in winter group compared to the other groups. Egg production was the lowest in the control group compared to the other groups. Birds kept under high environmental temperature had the lowest hematocrit value than the other treatment groups. In general, Egyptian winter conditions had adversely influence on most studied traits in Japanese quail. It is assumed, therefore, that during winter increased lighting period and ambient temperature are important to increase productive and reproductive cycles in Japanese quail by enhancing physiological responses.

Keywords: Japanese quail, cold stress, light period, egg production, rectal temperature, hematocrit value

\section{INTRODUCTION}

Light period and ambient temperature are two environmental variables principally affecting certain activities associated with productive and reproductive cycles in birds (Farner, 1964). The influence of photoperiodism on gonadal activity, sexual maturity, feed consumption, weight gain and egg production in Japanese quail was investigated by many research groups (Brain et al., 1988; Chaturvedi et al., 1991; Tsuyoshi and Wada, 1992; Wada, 1993; Canonaco et al., 1994 and Bonn et al., 2001). Temperature during rearing is a major factor in production efficiency for chickens (May and Lott, 2000). Ambient temperature has been reported to influence the productive and reproductive traits in previous works (Mohan et al., 1990 and Khalil, 1998).

Photoperiod plays an important role in the development of gonads in both male and female quails. The role of photoperiod information is to stimulate the hypothalamus area via eyes and extra-retinal photoreceptors, that provides inputs to the hypothalamus area to secrete gonadotropin-releasing hormone $(\mathrm{GnRH})$, which

Issued by The Egyptian Society of Animal Production 
controls secretions of FSH and LH hormones. In males, LH controls the production of the major sex steroid (testosterone) secreted by Leydig cells in the testes. In females, the secretion of FSH and LH controls the secretion of estrogen, necessary for yolk precursor lipoprotein secretion by the liver, oviduct and follicle development. Gonadotropin-releasing hormone stimulate gonadal development, eventually resulting in onset of lay (Bacon et al., 1980; Dunn and Sharp, 1990 and Lewis et al., 1999). Day length has a major effect on protein synthesis rates, this effect will determine the overall growth of chicks subjected to differing day lengths (Bonn et al., 2001). When Japanese quail chicks were raised on long (16h light/d) or short ( $8 \mathrm{~h} \mathrm{light/d)} \mathrm{photoperiods} \mathrm{from} 22$ to 70 days of age, only the quails raised on the long photoperiod layed eggs, starting between 42 and 49 days of age (Brain et al., 1988). The objective of this research was to study the effect of increasing photoperiod and ambient temperature during winter on the performance and thermoregulatory response in Japanese quail. Normal Egyptian winter conditions of temperature and light were compared with artificially prolonged daylight and an artificially increased ambient temperature.

\section{MATERIALS AND METHODS}

\section{Birds and husbandry}

The experiment was carried out at the Poultry Farm, Department of Animal Production, Faculty of Agriculture, Suez Canal University, Ismailia, Egypt during winter months (November till April). Chicks were kept under normal brooding conditions in brooding batteries 3 weeks of age, under continuous lighting and with a gradual decrease in room temperature from $37^{\circ} \mathrm{C}$ at hatching to $25^{\circ} \mathrm{C}$ at 3 weeks of age .

At 3 weeks of age, 195 birds were randomly distributed into three experimental groups and transferred to experimental floor pens $(3 \times 3 \mathrm{~m})$. Each group consisted of 65 chicks ( 25 males and 40 females). Both feed and water were provided ad libitum. All the chicks were wing numbered. The three experimental groups were classified as following. The first group (control) was kept under natural climatic conditions of the winter season, averaged light period $(11.3 \mathrm{~h} / \mathrm{d})$, mean temperature $\left(19.02^{\circ} \mathrm{C}\right)$ and mean relative humidity (53\%). The second group (lighted group) had similar conditions as winter group except that day light-length was extended artificially to be 16 hours daily. The last group (heated group) was kept under natural winter day light and averaged relative humidity (44\%) but ambient temperature raised to $31-32^{\circ} \mathrm{C}$.

\section{Studied Traits}

The live body weights of the males and females were recorded at $3,4,5,6,8,10$, 12 and 14 weeks of age. Feed and water consumptions were recorded throughout the experiment. The daily egg production rates were recorded up to 15 weeks of age. Sexual maturity, laying rate (\%), egg number, egg weight $(\mathrm{g})$ and egg mass $(\mathrm{g})$ were recorded. Body temperature $\left({ }^{\circ} \mathrm{C}\right)$ was recorded weekly, starting at 3 till 14 weeks of age on twenty birds randomly (10 males and 10 females) from each group by inserting thermometer $1.5 \mathrm{~cm}$ into the rectum for 30 second.

Blood samples were taken for measuring the hematocrit value. The samples were collected by cardiac puncture using a heparinized syringe. One hundred and twenty samples were obtained randomly at 12 and 14 weeks of age from 16 birds from each treatment group ( 8 males and 8 females). The hematocrit was measured after 
centrifuging the sample at $3000(\mathrm{r} / \mathrm{min})$ for 15 minutes. Mortality rates were determined at the end of the experimental period.

\section{Statistical Analysis}

Data were analysed using the General Linear Model (GLM) procedure of SAS (SAS, 1990).

\section{RESULTS AND DISCUSSION}

\section{Body weight and weight gain}

The initial body weight of three-week-old quail birds was nearly similar between the three treatments and ranged between (97.84-102.57 and 102.02-107.07 g) for males and females, respectively (Table 1). With age progress significant differences $(\mathrm{P} \leq 0.05)$ among treatments in females body weights were found. The lightest body weights were obtained in females kept under winter conditions, while the heaviest body weights were obtained in females kept under long day photoperiod and high environmental temperature. At 10 and 12 weeks of age, females kept under long day photoperiod had significantly heavier live body weights than females kept under other housing conditions. Considering males body weight, there were no significant differences between housing conditions in males live body weight at all ages studied, except at 6 and 8 weeks of age.

Table 1. Body weights (g) of male and female quail kept under different housing conditions (LSQ-Means \pm SD)

\begin{tabular}{ccccc}
\hline $\begin{array}{c}\text { Age } \\
\text { (wks) }\end{array}$ & Sex & \multicolumn{3}{c}{ Housing conditions } \\
\cline { 3 - 5 } 3 & Male & $102.57 \pm 12.44$ & $97.84 \pm 11.14$ & Heated \\
\hline \multirow{2}{*}{4} & Female & $107.07 \pm 19.13$ & $102.02 \pm 9.11$ & $102.57 \pm 10.57$ \\
\hline \multirow{2}{*}{5} & Male & $142.62 \pm 17.99$ & $138.21 \pm 15.89$ & $137.24 \pm 10.34$ \\
& Female & $147.32 \pm 14.17$ & $145.25 \pm 11.71$ & $141.05 \pm 10.81$ \\
\hline \multirow{2}{*}{6} & Male & $171.00 \pm 17.28$ & $175.28 \pm 20.58$ & $171.52 \pm 13.01$ \\
& Female & $182.62 \pm 16.93$ & $182.17 \pm 18.35$ & $177.58 \pm 10.39$ \\
\hline \multirow{2}{*}{8} & Male & $182.28 \pm 16.15^{\mathrm{b}}$ & $195.36 \pm 23.39^{\mathrm{a}}$ & $188.44 \pm 18.41^{\mathrm{ab}}$ \\
& Female & $196.00 \pm 16.22^{\mathrm{b}}$ & $209.37 \pm 18.06^{\mathrm{a}}$ & $210.94 \pm 12.32^{\mathrm{a}}$ \\
\hline \multirow{2}{*}{10} & Male & $182.54 \pm 17.33^{\mathrm{b}}$ & $198.36 \pm 27.38^{\mathrm{a}}$ & $204.64 \pm 23.31^{\mathrm{a}}$ \\
& Female & $195.81 \pm 16.56^{\mathrm{b}}$ & $232.11 \pm 29.59^{\mathrm{a}}$ & $234.75 \pm 16.89^{\mathrm{a}}$ \\
\hline \multirow{2}{*}{12} & Male & $197.62 \pm 17.50$ & $209.29 \pm 25.55$ & $206.16 \pm 23.32$ \\
& Female & $210.91 \pm 21.21^{\mathrm{c}}$ & $243.05 \pm 25.14^{\mathrm{a}}$ & $230.71 \pm 24.22^{\mathrm{b}}$ \\
\hline \multirow{2}{*}{14} & Male & $195.15 \pm 21.21$ & $204.08 \pm 28.08$ & $203.48 \pm 25.21$ \\
& Female & $206.89 \pm 20.61^{\mathrm{c}}$ & $242.61 \pm 26.92^{\mathrm{a}}$ & $228.81 \pm 26.44^{\mathrm{b}}$ \\
\hline
\end{tabular}

a,b,c Means in any row with no common superscript differ $(\mathrm{P} \leq 0.05)$. 
It must be mentioned that males kept under normal Egyptian conditions had the lightest values of body weight from 5 weeks old until the end of the experiment at 14 weeks of age. The average body weight gain values of quail chicks raised under different housing conditions revealed significant differences due to the housing conditions at most studied ages. From 3-4 weeks weight gain did not differ significantly between housing conditions. Weight gain of males was significantly higher in lighted group than in the control group during 4-5, 5-6 and 3-6 weeks of age. On the other hand, from 5-6 and 3-5 weeks females weight gain was significantly lower in control group compared with other groups. Average weight gain of male and female quails raised under winter conditions, long day photoperiod and high environmental temperature were $(82.01,97.52$ and $90.16 \mathrm{~g}$ for males and $90.93,107.35$ and $108.37 \mathrm{~g}$ for females) from 3 to 6 weeks of age, respectively. In general, quails raised under the winter conditions had the least weight gain than those from other housing conditions (Table 2).

Table 2. Weight gain (g) in male and female quail kept under different housing conditions (LSQ-Means \pm SD)

\begin{tabular}{ccccc}
\hline \multirow{2}{*}{$\begin{array}{c}\text { Age } \\
\text { (wks) }\end{array}$} & Sex & \multicolumn{3}{c}{ Housing conditions } \\
\cline { 3 - 5 } & & Control & Lighted & Heated \\
\hline \multirow{2}{*}{$3-4$} & Male & $40.05 \pm 9.28$ & $40.36 \pm 7.01$ & $38.96 \pm 4.96$ \\
& Female & $40.25 \pm 15.56$ & $43.22 \pm 7.49$ & $38.47 \pm 6.16$ \\
& Overall & $40.11 \pm 13.25^{\mathrm{ab}}$ & $41.79 \pm 6.22^{\mathrm{a}}$ & $38.71 \pm 5.55^{\mathrm{b}}$ \\
\hline \multirow{2}{*}{$4-5$} & Male & $28.37 \pm 12.73^{\mathrm{b}}$ & $37.08 \pm 10.12^{\mathrm{a}}$ & $34.28 \pm 5.55^{\mathrm{ab}}$ \\
& Female & $35.31 \pm 9.591$ & $36.92 \pm 14.54$ & $36.66 \pm 7.74$ \\
& Overall & $31.85 \pm 5.24^{\mathrm{b}}$ & $37.01 \pm 11.26^{\mathrm{a}}$ & $35.47 \pm 7.81^{\mathrm{ab}}$ \\
\hline \multirow{2}{*}{$5-6$} & Male & $12.58 \pm 5.24^{\mathrm{b}}$ & $20.08 \pm 11.02^{\mathrm{a}}$ & $16.91 \pm 7.81^{\mathrm{ab}}$ \\
& Female & $14.17 \pm 6.54^{\mathrm{c}}$ & $27.21 \pm 15.47^{\mathrm{b}}$ & $33.34 \pm 10.35^{\mathrm{a}}$ \\
& Overall & $13.37 \pm 6.01^{\mathrm{b}}$ & $23.64 \pm 13.27^{\mathrm{a}}$ & $25.12 \pm 10.11^{\mathrm{a}}$ \\
\hline \multirow{2}{*}{$3-6$} & Male & $82.01 \pm 10.21^{\mathrm{b}}$ & $97.52 \pm 15.14^{\mathrm{a}}$ & $90.16 \pm 10.11^{\mathrm{ab}}$ \\
& Female & $90.93 \pm 10.92^{\mathrm{b}}$ & $107.35 \pm 16.21^{\mathrm{a}}$ & $108.37 \pm 15.21^{\mathrm{a}}$ \\
& Overall & $86.47 \pm 9.11^{\mathrm{b}}$ & $102.43 \pm 15.61^{\mathrm{a}}$ & $99.25 \pm 13.61^{\mathrm{a}}$ \\
\hline $\mathrm{a}$ & & &
\end{tabular}

a,b,c Means in any row with no common superscript differ $(\mathrm{P} \leq 0.05)$.

These results are consistent with previous investigations. There are a correlation between rearing photoperiod and productivity of Japanese quail, because long day photoperiod resulted in increasing the period of feed intake and stimulated the gonadotropin hormones and sex hormones secretion, which are responsible for growth and sexual maturity (Dunn and Sharp, 1990 and Lewis et al., 1999). Also, day length has a major effect on protein synthesis rates (Bonn et al., 2001). 


\section{Feed and water consumptions and feed conversion}

The amount of feed consumed/chick for chicks kept under control, lighted and heated conditions were $(443.52,480.51$ and $467.27 \mathrm{~g})$ through 3 to 6 weeks old, respectively (Table 3 ). The amounts of feed consumed/chick increased with long photoperiod. On the other hand high housing temperature and short photoperiod/day (normal Egyptian conditions) decreased the amounts of feed consumed/chick. The respective feed conversions were 5.1, 4.7 and 4.7. Lighting and heating, obviously, resulted in better efficiency of feed utilization. The amount of water consumed/chick of chicks kept under natural winter condition (control), lighting and heating were $(557.3,594.0$ and $825.1 \mathrm{ml})$ through 3 to 6 weeks old, respectively. Chicks kept under high environmental temperature consumed more water than those under the other housing conditions. These results agree with those obtained by Macled and Dabutha (1997) who found that, water consumption (ml) increased with increased temperature (by about $60 \%$ at $35^{\circ} \mathrm{C}$ ).

Table 3. Feed intake, feed conversion and water consumption in quail with respect to housing conditions

\begin{tabular}{lcccc}
\hline \multirow{2}{*}{ Parameters } & & \multicolumn{3}{c}{ Housing conditions } \\
& & Age (wks) & \\
\cline { 3 - 5 } & & Control & Lighted & Heated \\
\hline \multirow{2}{*}{ Feed intake (g) } & $3-4$ & 141.33 & 120.50 & 132.11 \\
& $4-5$ & 149.17 & 177.17 & 165.9 \\
& $5-6$ & 153.02 & 182.84 & 169.26 \\
& $3-6$ & 443.52 & 480.51 & 467.27 \\
Feed conversion & $3-4$ & 3.523 & 2.883 & 3.418 \\
& $4-5$ & 4.683 & 4.787 & 4.677 \\
& $5-6$ & 11.411 & 7.613 & 6.731 \\
Water & $3-6$ & 5.129 & 4.691 & 4.708 \\
(ml) & $3-4$ & 184.5 & 198.5 & 250 \\
& $4-5$ & 183.8 & 197.9 & 285.3 \\
& $5-6$ & 189.1 & 197.6 & 289.7 \\
\hline \multirow{2}{*}{ consumption } & $3-6$ & 557.3 & 594 & 825.1 \\
\hline
\end{tabular}

\section{Sexual maturity}

Results in Table (4) showed that, quails raised under the Egyptian natural winter conditions (control) had delayed age at $12 \%$ laying than the long day photoperiod and high ambient temperature conditions (98, 46 and 40 days, respectively). Significant differences $(\mathrm{P} \leq 0.05)$ in body weight at $12 \%$ egg laying were found due to housing conditions mean while, birds kept under high environmental temperature had significantly less body weight than those kept under natural winter conditions and long-day photoperiod by about $6.90 \%$. 
Table 4. Egg production parameters with respect to housing conditions from 5 to 15 weeks of age (LSQ-Means \pm SD)

\begin{tabular}{lccc}
\hline \multirow{2}{*}{ Parameters } & \multicolumn{3}{c}{ Housing conditions } \\
\cline { 2 - 4 } & Control & Lighted & Heated \\
\hline $\begin{array}{l}\text { Age at } 12 \% \text { egg Production } \\
\text { (day) }\end{array}$ & 98 & 46 & 40 \\
Body weight at $12 \%$ egg & $215.02 \pm 24.28^{\mathrm{a}}$ & $215.15 \pm 15.61^{\mathrm{a}}$ & $200.23 \pm 9.88^{\mathrm{b}}$ \\
Production (g) & & & \\
Egg number/hen (n) & 2.11 & 36.17 & 42.92 \\
Egg weight (g) & $11.41 \pm 0.88^{\mathrm{a}}$ & $11.05 \pm 1.01^{\mathrm{b}}$ & $10.79 \pm 1.05^{\mathrm{b}}$ \\
Egg mass/hen (g) & 24.07 & 399.60 & 461.39 \\
\hline
\end{tabular}

$\mathrm{a}, \mathrm{b}$ Means in any row with no common superscript differ $(\mathrm{P} \leq 0.05)$.

\section{Egg production trait:}

\section{Laying rate, egg number, weight and mass}

Average weekly percentage of egg production as affected by housing conditions from 5 to 15 weeks of age are presented in (Figure 1). Birds kept under high environmental temperature showed a rapid start of egg laying at 5 weeks of age. They showed $50 \%$ laying rate at the $7^{\text {th }}$ week with successive increase to reach its maximum $(86.91 \%)$ at 10 weeks, thereafter, it decreased slowly up to 13 weeks $(57.40 \%)$ when it increased again up to 15 weeks to be $75 \%$. Birds kept under long day light photoperiod showed rapid start of egg laying at 5 weeks, the $50 \%$ rate of lay was recorded at the $8^{\text {th }}$ week and increased to reach its peak $(70.27 \%)$ at 11 weeks of age, thereafter, it decrease at the $12^{\text {th }}$ week $(62.65 \%)$ and increased again up to the end of the experiment. Birds kept under winter condition (control) showed delayed egg laying to the $11^{\text {th }}$ week of age. Rate of lay was increased slowly with age to reach $(11.58 \%)$ at the end of the experiment.

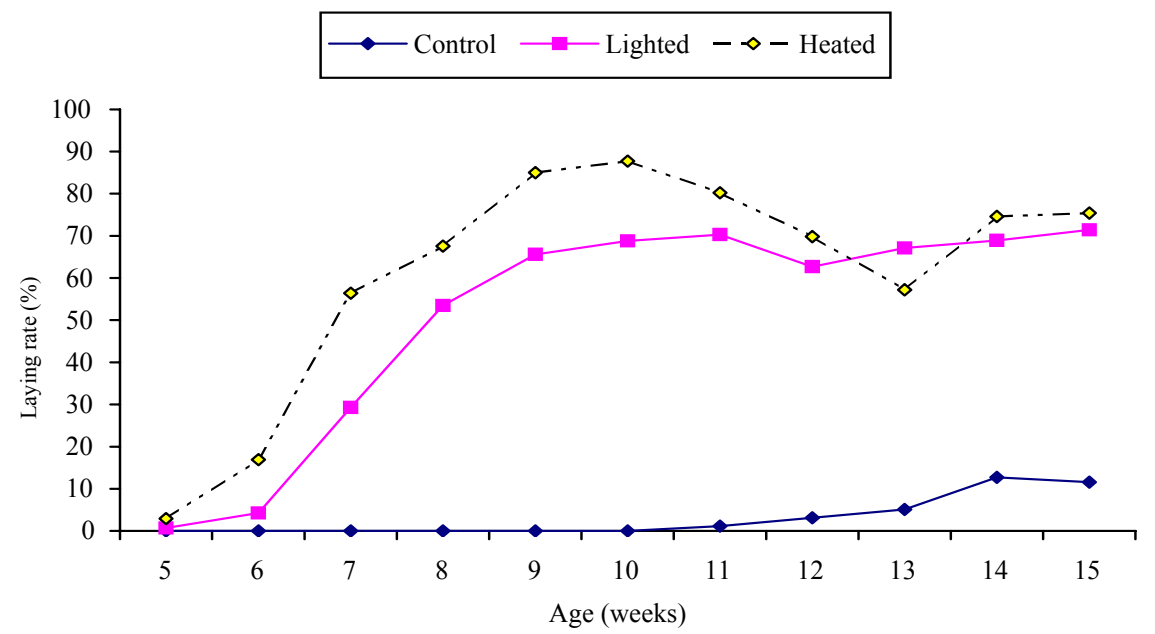

Fig. 1. Laying rate with respect to housing conditions 
Quail birds kept under high environmental temperature gave higher number of eggs and greater egg mass through 5 to 15 weeks of age (42.92 egg and $464.39 \mathrm{~g}$, respectively), while lower values were obtained from birds kept under normal Egyptian winter conditions (2.11 eggs and 24.07g, respectively). Birds kept under winter conditions had significantly heavier egg weights than those kept under long day photoperiod and high environmental temperature $(11.41,11.05$ and $10.79 \mathrm{~g}$, respectively).

These results are consistent with Kuit (1980) and Brake \& Baughman (1989) who reported that increasing daylight $(16 \mathrm{~h} / \mathrm{d})$ resulted in an earlier onset of lay and sexual maturity, less feed consumed per hen to peak egg production, improved feed conversion, an earlier age at peak egg production, higher peak egg production and more total egg production per hen than under a regimen with an $8 \mathrm{~h}$ photoperiod supplied by daylight during the growing period in broiler breeders. Wilson et al., (1970) found that egg production was greater and the weights of gonads and oviducts were significantly larger, the egg weight was smaller in Japanese quail kept under hot environment $32^{\circ} \mathrm{C}$ with short day $(8 \mathrm{~h} / \mathrm{d})$ than in quail kept under a cold environment $10^{\circ} \mathrm{C}$ with short day $(8 \mathrm{~h} / \mathrm{d})$.

\section{Hematocrit values}

Hematocrit values did not differ significantly between the three groups at any age in male. While, significant difference was found in female at 12 and 14 weeks of age. Females kept under high environmental temperature had the lower hematocrit values than quails kept under both winter conditions (control) and long day photoperiod at 12 and 14 weeks of age. In General, birds kept under high environmental temperature had the lower hematocrit values than quails kept under both winter conditions (control) and long day photoperiod (39.82, 41.06 and $45.87 \%$ at 12 weeks of age and 39.53, 43.92 and $42.85 \%$ at 14 weeks of age), respectively (Table 5).

These results agree with Shlosberg et al. (1992) who found that cold-stressed birds show a rapidly developing elevated hematocrit. Hematocrit values at 42 day of age ranged between 27 to $55 \%$, the higher values being caused by exposure to low ambient temperatures (Shlosberg and Bellaivhe, 1996). Lowered hematocrit is caused by less erythrocytes and no more fluid in the blood volume or smaller erythrocytes.

The definition of high and low hematocrit is somewhat difficult as this may vary greatly, depending on environmental factors related to ambient temperature, age, sex, water intake, dietary sodium, copper and iron (Goodwin et al., 1992). In the present study a negative correlation was found between water consumed and hematocrit value $(-0.39)$ with highly significant correlation (Table 6). These results indicate that high environmental temperature causes decreases in hematocrit values by increased water consumption. 
Table 5. Hematocrit values of male and female quails with respect to housing conditions (LSQ-Means \pm SD)

\begin{tabular}{ccccc}
\hline \multirow{2}{*}{$\begin{array}{c}\text { Age } \\
\text { (wks) }\end{array}$} & Sex & \multicolumn{3}{c}{ Housing conditions } \\
\cline { 3 - 5 } & Male & $45.98 \pm 4.31$ & $45.23 \pm 3.27$ & $45.05 \pm 2.82$ \\
\multirow{2}{*}{12} & Female & $45.77 \pm 5.91^{\mathrm{a}}$ & $36.89 \pm 5.94^{\mathrm{b}}$ & $34.59 \pm 3.99^{\mathrm{b}}$ \\
& Overall & $45.87 \pm 4.67^{\mathrm{a}}$ & $41.06 \pm 5.01^{\mathrm{b}}$ & $39.82 \pm 3.25^{\mathrm{b}}$ \\
\hline \multirow{2}{*}{14} & Male & $46.01 \pm 3.03$ & $45.62 \pm 1.10$ & $42.63 \pm 4.71$ \\
& Female & $39.69 \pm 5.81^{\mathrm{ab}}$ & $42.22 \pm 3.66^{\mathrm{a}}$ & $36.43 \pm 3.99$ \\
& Overall & $42.85 \pm 4.75$ & $43.92 \pm 2.56$ & $39.53 \pm 4.25$ \\
\hline \multirow{2}{*}{ Overall } & Male & $46.17 \pm 3.51$ & $45.43 \pm 2.38$ & $43.84 \pm 3.56$ \\
& Female & $42.73 \pm 5.85^{\mathrm{a}}$ & $39.56 \pm 4.56^{\mathrm{a}}$ & $35.71 \pm 3.98^{\mathrm{b}}$ \\
& Overall & $44.45 \pm 4.31^{\mathrm{a}}$ & $42.49 \pm 3.85^{\mathrm{ab}}$ & $39.77 \pm 3.64^{\mathrm{b}}$ \\
\hline
\end{tabular}

a,b Means in a row with no common superscript differ $(\mathrm{P} \leq 0.05)$.

\section{Rectal temperature}

After birds were randomly distributed into the three experimental groups and transferred to the experimental floor pens, the rectal temperature rose rapidly in all experimental groups up to the $5^{\text {th }}$ week in heated and lighted groups and at $6^{\text {th }}$ week in control group, after that rectal temperature dropped in all experimental groups (Fig. 2). In general, rectal temperature was significantly higher in birds kept under normal Egyptian conditions than in those from the other two experimental groups at $6,7,9$ until 14 weeks of age irrespective of sex. This indicates that lighting and heating groups acclimatized more rapidly than the normal group. Because the decreased rectal temperature indicates that, these birds had increased food and energy intake and the metabolic process is normal (Sykes and Silah, 1986). On the other hand, the correlation between rectal temperature and acclimatized are given. The negative correlation was found between rectal temperatures with feed intake and water consumption with highly significant correlation $(-0.27 \&-0.23)$, respectively (Table 6).

\section{Correlation estimates}

The results of correlation coefficients between some studied traits showed that, positive correlation was found between body weight and both feed intake and water consumption with highly significant correlation (Table 6). In contrast, negative correlation was found between both rectal temperature and hematocrit value and both feed intake and water consumption with highly significant correlation. These results indicated that, increase of feed intake follow-up increase in body weight. On the other hand, increase of water consumption follow-up decrease in hematocrit rate. 


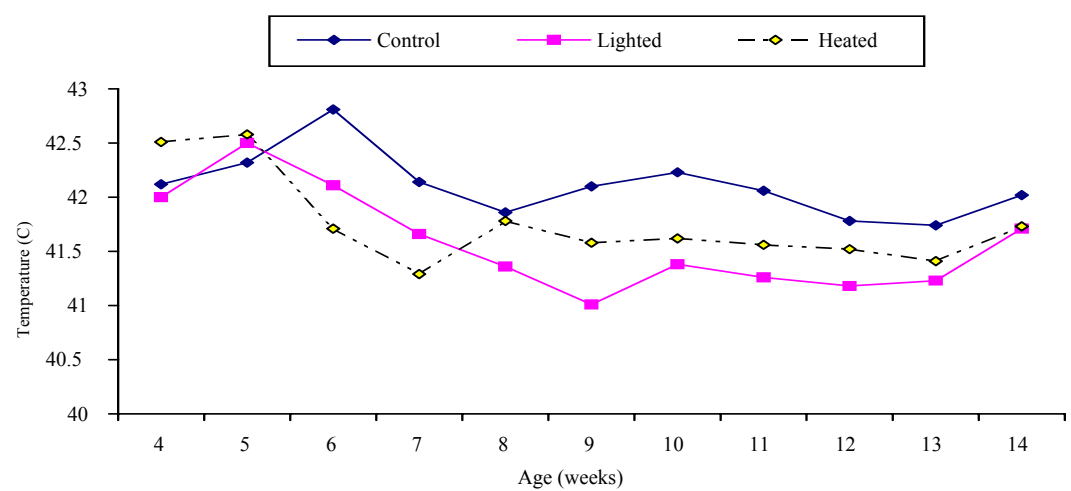

Fig. 2. Weekly average of rectal temperature $\left({ }^{\circ} \mathrm{C}\right)$ of quail with respect to housing Conditions till 14 weeks of age

Table 6. Correlation coefficients between rectal temperature $\left({ }^{\circ} \mathrm{C}\right)$ and productive traits, across housing conditions

\begin{tabular}{cccccc}
\hline & $\mathrm{RT}$ & $\mathrm{BW}$ & $\mathrm{HT}$ & $\mathrm{FC}$ & $\mathrm{WC}$ \\
\hline RT & 1.000 & $0.03 \mathrm{~ns}$ & $-0.02 \mathrm{~ns}$ & $-0.27^{* *}$ & $-0.23^{* *}$ \\
BW & & 1.000 & $-0.12 \mathrm{~ns}$ & $0.23^{* *}$ & $0.27^{* *}$ \\
HT & & & 1.000 & $-0.16^{* *}$ & $-0.39^{* *}$ \\
FC & & & & 1.000 & $0.56^{* *}$ \\
WC & & & & & 1.000 \\
\hline
\end{tabular}

$\mathrm{RT}=$ rectal temperature, $\mathrm{BW}=$ body weight, $\mathrm{HT}=$ hematocrit value,

$\mathrm{FC}=$ feed conversion, $\mathrm{WC}=$ water consumption

\section{Mortality rate}

Mortality rates of males and females, as affected by housing conditions are presented in Table (7). Females had a higher mortality rate than males (11.66 vs. $2.66 \%$, respectively), irrespective of treatments. Also, higher mortality rates were obtained in birds housed under long day photoperiod compared to those kept under both high environmental temperature and winter conditions $(10.66,7.69$ and $6.16 \%$, respectively), during the experimental period. The reason of high mortality rate in the lighted group compared to other groups may be return to activity and sexual actives of birds under long day photoperiod.

Table 7. Total mortality rate of male and female quail at 14 weeks of age with respect to housing conditions

\begin{tabular}{cccccccccc}
\hline \multirow{2}{*}{$\begin{array}{c}\text { Age } \\
\text { (wks) }\end{array}$} & \multirow{2}{*}{ Sex } & \multicolumn{2}{c}{ Control } & \multicolumn{2}{c}{ Lighted } & \multicolumn{2}{c}{ Heated } & \multicolumn{2}{c}{ Total } \\
& & No & $\%$ & No & $\%$ & No & $\%$ & No & $\%$ \\
\hline \multirow{2}{*}{ Initially } & Male & 25 & & 25 & & 25 & & 75 & \\
housed & Female & 40 & & 40 & & 40 & & 120 & \\
& Total & 65 & & 65 & & 65 & & 195 & \\
& Male & 1 & 4.00 & 1 & 4.00 & 0 & 0.00 & 2 & 2.66 \\
At 14 wk & Female & 3 & 7.50 & 6 & 15.00 & 5 & 12.5 & 14 & 11.66 \\
& Total & 4 & 6.15 & 7 & 10.76 & 5 & 7.69 & 16 & 8.20 \\
\hline
\end{tabular}




\section{REFERENCES}

Bacon, W.L., K.I. Brown and M.A. Musser, 1980. Changes in plasma calcium, phosphorus, lipids and estrogens in turkey hens with reproductive state. Poultry Sci. 59:444-452.

Bonn, B., P.W. Watt, K. Smith and G.H. Visser, 2001. Day length has a major effect on the response of protein synthesis rates to feeding in growing Japanese quail. J. Nutr. Feb., 131(2): 268-275.

Brain, P.C., O. Onagbesan, M. Peddie and T. Taylor, 1988. Changes in plasma concentrations of reproductive steroids in female Japanese quail raised on long or short photoperiods. Gen. Comp. Endocrinol, 69(2): 174-180.

Brake, J. and G.R. Baughman, 1989. Comparison of lighting regimes during growth on subsequent seasonal reproductive performance of broiler breeders. Poultry Sci. 68:79-85.

Canonaco, M., R. Tavolaro, R.M. Facciolo, C. Artero and M.F. Franzoni, 1994. Combined gonadal and photic influences on 2-[125I] iodomelatonin-binding level changes in some brain areas of the quail. Exp. Zool. 15; 269(4): 383-388.

Chaturvedi, C., A. Meier and R. Bhatt, 1991 Effect of $12 \mathrm{hr}$ temporal relation of serotonin and dopamine precursor drugs (5-HTP and L-DOPA) on photosexual responses of immature Japanese quail. Indian, J. Exp. Biol. 29(4): 342-345.

Dunn, I. C. and P.J. Sharp, 1990. Photoperiodic requirements for LH release in Juvenile broiler and egg-laying strains of domestic chickens fed ad libitum or restricted diets. J. Reprod. Fertil. 90: 329-335.

Farner, D. S. 1964. The photoperiodic control of reproductive cycle in birds. Am., scientist, 52:137-156.

Goodwin, M., J. Davis and J. Brown, 1992. Packed cell volume reference intervals to aid in the diagnosis of anemia and polycythemia in young broiler chickens. Avian Dis. 36:440-443.

Khalil, H.A., 1998. Seasonal variation in production and fertility of Japanese quail (Coturinx coturnix japonica). M.Sc. Thesis, Suez Canal University, Faculty of Agriculture.

Kuit, A. R., 1980. the effect of light treatments on hatching egg performance of dwarf broiler mothers. Poultry Sci. 59:1629.(Abstr.).

Lewis, P.D., G.C. Perry, T.R. Morris and J.A. Douthwaite, 1999. Effect of timing and size of photoperiod change on plasma FSH concentration and the correlation between FSH and age at first egg in pullets. British Poultry Sci. 59:444-452.

Macled, M.G. and L.A. Dabutha, 1997. Diet selection by Japanese quail (Coturnix coturnix japonica) in relation to ambient temperature and metabolic rate. British Poultry Sci. 38 : 586-589.

May, J. D. and B.D. Lott, 2000. The effect of environmental temperature on growth and feed conversion of broiler to 21 days of age. Poultry Sci. 79:669-671.

Mohan, J., R.P. Moudgal and N.B. Singh, 1990. Angiotensin-converting- enzyme activity in epididymis, vas deferens and spermatozoa of domestic cock. Animal Reproduction Sci. 23 (4) 349 - 354.

SAS Institute, 1990. SAS statistical guide for personal computer, SAS Institute Inc. Cary, NC.

Shlosberg, A. and M. Bellaivhe, 1996. Hematocrit values and mortality from ascites in cold-stressed broilers from parents selected by hematocrit. Poultry Sci. 75:1-5. 
Shlosberg, A., I. Zadikov, U. Bendheim, V. Handji and E. Berman, 1992. The effects of poor ventilation, low temperatures, type of feed and sex of birds on the development of ascites in broilers. Avian Pathol. 21:369-382.

Sykes, A. H. and F.I. Silah, 1986. Effect of a changes of dietary energy intake and environmental temperature on heat tolerance in the fowl. British Poultry Sci. 27:687-693.

Tsuyoshi, H. and M. Wada, 1992. Termination of LH secretion in Japanese quail due to high-and low-temperature cycles and short daily photoperiods. Gen. Comp. Endocrinol. 85(5): 424-429.

Wada, M. 1993. Low temperature and short days together induce thyroid activation and suppression of LH release in Japanese quail. Gen. Comp. Endocrinol. 90 (3): 355-363.

Wilson, W.O., J.R. Cain and T.D. Siopes, 1970. The interaction of light and temperature in Coturnix. Poultry Sci. 20:204-207. 


\section{دراسة أثر نظم الإيواء على أداء السمان اليابانى تحت ظروف الجو البارد فى فصل الشتاء}

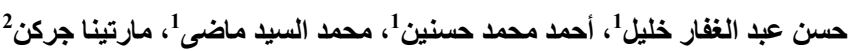

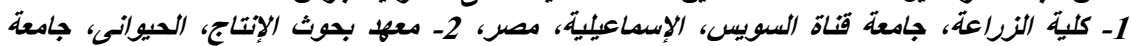
جوتنجن، ألمانيا

إستهدفت هذه التجربة دراسة تأثير طول فترة الإضاءة أو زيادة درجة الحر ارة أثناء فترة التربية على أداء

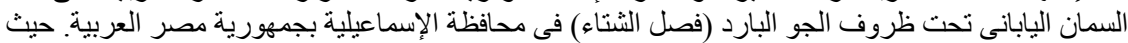

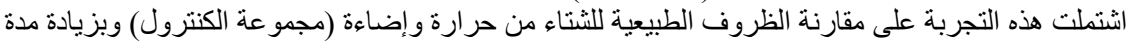

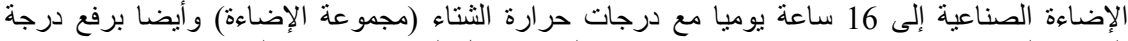

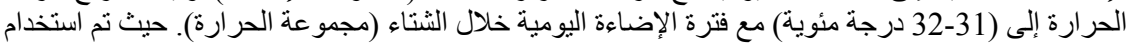

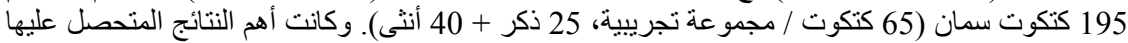

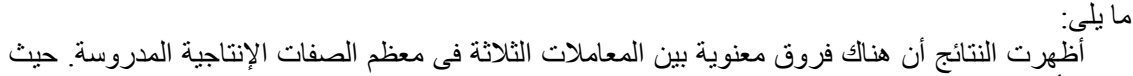

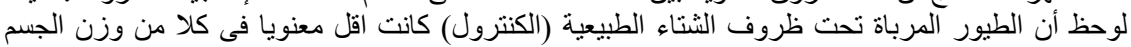

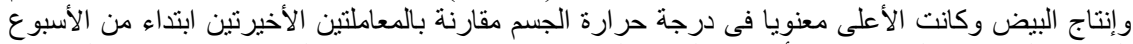

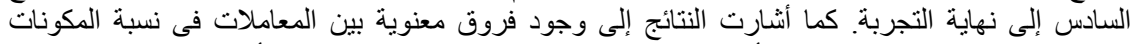

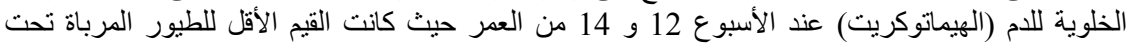

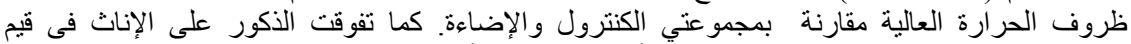

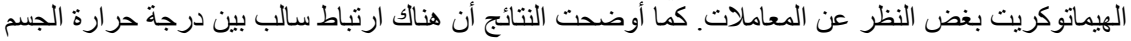

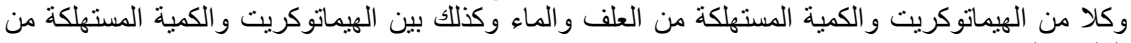
العلف و الماء.

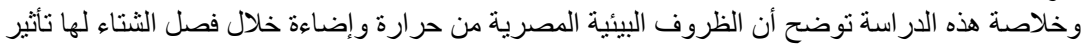

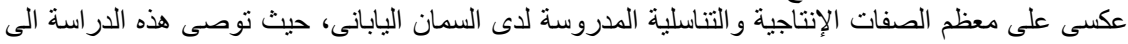

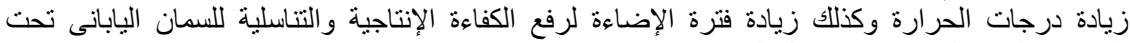

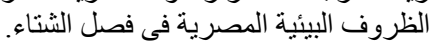

